\title{
Pomiar wartości społecznej na przykładzie Fundacji Sławek
}

\author{
Aleksandra Snarska* \\ Streszczenie: Artykuł ma na celu prezentację dotychczas wypracowanych metod pomiaru wartości społecz- \\ nej generowanej przez przedsiębiorstwa społeczne na przykładzie Fundacji Sławek. Fundacja ta \\ świadczy pomoc więźniom i recydywistom oraz ich rodzinom, mając na celu przywrócenie ich \\ społeczeństwu, tak aby byli zdolni żyć w pełni i w zgodzie z literą prawa. Artykuł zawiera skrótową \\ prezentację kategorii oddziaływania (wpływu) społecznego, wartości społecznej oraz najpow- \\ szechniej stosowanych metod jej pomiaru: modelu logicznego (teorii zmiany) oraz SROI, a następ- \\ nie ukazuje sposób ich wykorzystania na przykładzie Fundacji Sławek. \\ Słowa kluczowe: wartość społeczna, model logiczny, teoria zmiany, SROl.
}

\section{Wprowadzenie}

Wiedza na temat pomiaru wartości społecznej, jej efektów, funkcji i istoty nie jest głęboka ani powszechna [Perek-Białas, Worek, 2007, s. 154]. Szybko jednak rośnie zainteresowanie tą dziedziną. Rozkwit inwestowania odpowiedzialnego społecznie, funduszy Unii Europejskiej oraz decentralizacja zarządzania środkami publicznymi doprowadziły w ostatnim dwudziestoleciu do znacznego zainteresowania pomiarem wartości społecznej wytwarzanej przez przedsiębiorstwo społeczne.

Niniejszy artykuł ma na celu prezentację dotychczas wypracowanych metod pomiaru oddziaływania społecznego (ang. social impact) podmiotów ekonomii społecznej na przykładzie Fundacji Sławek. Obszar badań dotyczyć będzie dwóch z najpowszechniej stosowanych metod pomiaru wartości - modelu logicznego (teoria zmiany) oraz pomiaru społecznego zwrotu z inwestycji SROI. Celem jest upowszechnianie stosowania owych metod pomiaru w tych organizacjach, w których jest to możliwe. Pominięte przy tym zostaną metody eksperymentalne, porównania z grupą kontrolną, których istnienie i waga podkreślone zostaną jedynie w części teoretycznej artykułu. Pominięcie tych bardzo istotnych badań porównawczych jest spowodowane ich wysokim kosztem oraz czasochłonnością.

\section{Pomiar oddziaływania społecznego}

Pomiar wartości w przypadku podmiotów ekonomii społecznej powinien mieć na celu zarówno analizę korzyści ekonomicznych, jak i oddziaływania społecznego i ekologicznego tych organizacji. Pomiar celów organizacji jest wówczas zgodny z ideą wartości mieszanej (ang. blended value), która uznaje, iż zarówno cele środowiskowe, społeczne, jak i ekonomiczne są istotne $w$ pomiarze wartości w przedsiębiorstwie i że wszystkie one powinny być raportowane interesariuszom [Olejniczak, 2014].

\footnotetext{
* Aleksandra Snarska

Kolegium Nauk o Przedsiębiorstwie Instytut Zarządzania Wartością

Szkoła Główna Handlowa

ul. Madalińskiego 31/33, 02-544 Warszawa

e-mail: aleksandra.snarska@gmail.com
} 
Rysunek 1. Schemat potrójnej linii przewodniej (wartość mieszana)
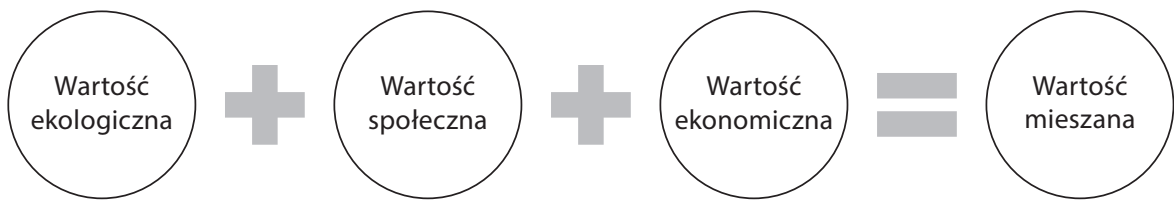

Źródło: opracowanie własne.

Sam pomiar wartości społecznej wytwarzanej przez przedsiębiorstwo, czyli jego oddziaływanie lub wpływ społeczny (ang. social impact) jest zbieżny z pomiarem celów społecznych oraz misji. Orientacja na misję w przedsiębiorstwie społecznym jest na tyle silna, iż wiele definicji przedsiębiorstwa społecznego za nieodłączny jego element uważa reinwestycję zysków na cele statutowe. Kluczowa dla zarządzania przedsiębiorstwem wartość NPV (wartość bieżąca netto) staje się wtórna wobec misji, gdyż nadrzędną wartością jest wprowadzanie pozytywnej zmiany społecznej czy podnoszenie jakości życia, a kluczowym interesariuszem są beneficjenci przedsiębiorstwa społecznego.

Kluczowa dla inwestycji w cele społeczne jest więc kategoria wpływu lub oddziaływania społecznego (ang. social impact). Według organizacji Ashoka wpływ można osiągać na różnych poziomach: od wymiernych efektów pracy z podopiecznymi organizacji, jej beneficjentami, którzy potrzebowali pomocy, poprzez wpływ skalowany - oddziaływanie na duże grupy, po szerszy wpływ na całe systemy i zachowania ludzi, normy, wartości i paradygmaty (patrz: tab. 1). Konieczna jest przy tym strategiczna wizja tego, na czym wpływ organizacji ma się koncentrować [Kim, 2015].

Przedsiębiorstwo społeczne może działać u podstaw, niosąc pomoc potrzebującym. Innym udaje się skalować model działania, nie tylko poprzez wzrost zasięgu własnej organizacji, ale także poprzez swojego rodzaju franczyzę stosowanych rozwiązań. Wywiady autorki artykułu z innowatorami społecznymi zrzeszonymi w organizacji wykazały, iż organizacje społeczne chętnie wypowiadają się na temat możliwości skalowania czy franczyzy swoich modeli działania. Niektórzy wypracowują poradniki, wdrażają swoje metodologie u innych, dają certyfikaty, dzielą się wiedzą (np. podczas konferencji). Co więcej, gospodarka sieciowa ułatwiła tworzenie ekosystemów czy sojuszy, polegających na współpracy grup organizacji o podobnych misjach, aby wspólnie wypracowywać swoje oddziaływanie społeczne i prowadzić jego pomiar dla całej grupy. Kolejny etap to zmiana systemowa, na poziomie całych rynków czy ekosystemów. Ostatecznie Ashoka mówi o zmianie modelu (ang. framework), co - jak wprowadzenie demokracji czy powszechnych praw człowieka - dotyczyć będzie całych społeczeństw.

Tabela 1. Cztery poziomy oddziaływania lub wpływu społecznego wg Ashoki

\begin{tabular}{|l|l|l|}
\hline Poziom wpływu & \multicolumn{1}{|c|}{ Opis } & \multicolumn{1}{c|}{ Przykłady } \\
\hline Rezultaty & $\begin{array}{l}\text { Praca u podstaw z ludźmi potrzebującymi pomocy. } \\
\text { Bezpośredni wpływ na ich dobrostan. Jasny i kon- } \\
\text { kretny wpływ, np. karmienie głodnych, szkolenie } \\
\text { bezrobotnych, udzielanie porad prawnych }\end{array}$ & $\begin{array}{l}\text { Jadłodajnie dla bezdomnych, schroniska dla psów, } \\
\text { porady prawne dla uchodźców }\end{array}$ \\
\hline
\end{tabular}




\begin{tabular}{|l|l|l|}
\hline Poziom wpływu & \multicolumn{1}{|c|}{ Opis } & \multicolumn{1}{|c|}{ Przykłady } \\
\hline $\begin{array}{l}\text { Oddziaływanie } \\
\text { społeczne }\end{array}$ & $\begin{array}{l}\text { Modele zwiększające efektywność i wpływ poprzez } \\
\text { dobrze zarządzaną logistykę danej interwencji lub } \\
\text { rozwiązania. Oddziaływanie na duże grupy }\end{array}$ & $\begin{array}{l}\text { Czerwony Krzyż, Americorps, przesiedlenia uchodź- } \\
\text { ców na dużą skalę }\end{array}$ \\
\hline $\begin{array}{l}\text { Zmiana } \\
\text { systemowa }\end{array}$ & $\begin{array}{l}\text { Nowe rozwiązanie, które odnosi się do źródła } \\
\text { problemu. Może chodzić o zmianę polityk, szerokie } \\
\text { przyjęcie danej metodologii przez liderów sektora } \\
\text { albo nowe zachowania na istniejącym rynku lub } \\
\text { w ekosystemie }\end{array}$ & Mikrokredyty, CSR, Wikipedia \\
\hline Zmiana modelu & $\begin{array}{l}\text { Wpływ na sposoby mý́lenia na wielką skalę, } \\
\text { które ostatecznie prowadzą do zmiany zachowań } \\
\text { społeczeństw. Nie jest to interwencja o charakterze } \\
\text { krajowym lub dotyczącym jednej dziedziny, ale } \\
\text { składa się na nią praca wielu organizacji celem zmiany } \\
\text { paradygmatu }\end{array}$ & $\begin{array}{l}\text { Uniwersalne prawa człowieka, prawa kobiet, prawa } \\
\text { obywatelskie, demokracja, idea społecznego start- } \\
\text {-upu }\end{array}$ \\
\hline
\end{tabular}

Źródło: [Kim, 2015].

Kategoria oddziaływania społecznego jest trudniejsza do wyrażenia w liczbach oraz bardziej zdywersyfikowana niż pojęcie wartości bieżącej netto czy wartości rynkowej przedsiębiorstw działających komercyjnie. Przysparza to wielu trudności w pomiarze, a także przybliżaniu potencjalnym inwestorom korzyści płynących z inwestycji odpowiedzialnych społecznie, czy zarządzaniu portfelem projektów etc. Wypracowano jednak szereg metodologii pomiaru oddziaływania społecznego organizacji, które są wykorzystywane zarówno przez prywatnych inwestorów, jak i przez instytucje pośredniczące $w$ dotowaniu projektów z funduszy UE czy budżetu państwa etc.

\section{Metody pomiaru wartości społecznej}

Istotny jest dobór odpowiednich metod badawczych. Należą do nich najpowszechniej wykorzystywany model logiczny (lub teoria zmiany), metody finansowe takie jak społeczny zwrot z inwestycji, który można wyrazić przykładowo jako zwrot z inwestycji lub wartość bieżącą netto. Najprecyzyjniejsze wydają się metody eksperymentalne - badania porównawcze z grupą kontrolną. Ex-post warto wykorzystywać metody badania beneficjentów, ich satysfakcji, sukcesów. Niniejsza część artykułu koncentrować się będzie na opisie tych metod.

Pomiar oddziaływania społecznego może być prowadzony: przed projektem w procesie analizy kondycji przedsiębiorstwa (celem szacowania możliwego wpływu), w czasie planowania go, ale także podczas monitoringu lub później dla oceny skuteczności i efektywności oraz racjonalności podjętych działań [Edens, Lall, 2014]. Przed przystąpieniem do pomiaru należy określić wyraźnie pożądane oddziaływanie społeczne projektu i na jego podstawie sformułować cele pomiaru czy tezę inwestycyjną (teorię zmiany) [IMWG, 2014].

\subsection{Model teorii zmiany (model logiczny)}

Teoria zmiany jest najpowszechniej stosowanym modelem pomiaru wartości dla przedsięwzięć o charakterze społecznym. Ukazuje ona proces przechodzenia od nakładów inwestycyjnych poprzez podejmowane aktywności, ich bezpośrednie wyniki, następnie rezultaty społeczne, po oddziaływanie społeczne w szerszym kontekście i dłuższym horyzoncie czasowym. Według V. Vogel interwencje społeczne są często wynikiem wielu przekonań, założeń i hipotez na temat tego, jak dochodzi do zmiany społecznej, jak działają ludzie, organizacje lub systemy polityczne, ekosystemy. Teoria zmiany pozwala je wszystkie 
wyartykułować [Vogel, 2012]. Jest kilka sposobów reprezentacji procesu zmiany będącej zamierzonym efektem ponoszonych nakładów, podejmowanych działań. W niniejszym artykule autorka skoncentruje się na najpowszechniej stosowanym tzw. modelu logicznym, który w sposób prosty charakteryzuje poszczególne etapy procesu prowadzącego do szerszego oddziaływania społecznego.

Model teorii zmiany zwiększa wydajność i przejrzystość w procesie ewaluacji interwencji społecznych, a także pozwala budować wspólne rozumienie jej celów u wszystkich zaangażowanych interesariuszy [Guthrie et al., 2005]. Kluczowa jest koncentracja na rezultatach, które przyjmują bardziej wymierną formę, ale także na oddziaływaniu długoterminowym. Konieczne może być wypracowanie odpowiednich benchmarków - standar- dów miary postępu danej interwencji, tego jak ma się ona $\mathrm{w}$ relacji do długoterminowych celów darczyńcy, budżetu państwa etc. i czy umożliwia zrobienie postępu na drodze do ich osiągnięcia.

Analiza oddziaływania społecznego organizacji na podstawie uprzednio zebranych i zweryfikowanych danych wymagać może określenia wpływu działań organizacji na zróżnicowanie wyników, redukcji wpływu czynników zewnętrznych oraz danych nieistotnych, a następnie przeprowadzenia porównań z podobnymi do naszego i innymi podmiotami, celem określenia efektywności własnych interwencji [Peersman, 2014]. Możliwe jest też ustalenie rezultatów docelowych interwencji oraz wdrożenie głównych wniosków z analizy teorii zmiany w działania zarządcze organizacji i podejmowanie decyzji.

\section{Rysunek 2. Uproszczony schemat modelu teorii zmiany}

\begin{tabular}{|c|c|c|c|c|}
\hline Nakłady & Aktywności & Wyniki & Rezultaty & Oddziaływanie \\
\hline $\begin{array}{l}\text { - Nakłady } \\
\text { finansowe } \\
\text { - Czas pracy } \\
\text { - Liczba pracow- } \\
\text { ników } \\
\text { - Relacje z innymi } \\
\text { organizacjami }\end{array}$ & $\begin{array}{l}\text { - Działania } \\
\text { podjęte celem } \\
\text { osiągnięcia } \\
\text { wyników } \\
\text { - Np. szkolenia } \\
\text { lub zrealizowa- } \\
\text { ne kampanie }\end{array}$ & $\begin{array}{l}\text { • Bezpośrednie } \\
\text { wyniki } \\
\text { podjętych } \\
\text { aktywności } \\
\text { • Np. przeszkolo- } \\
\text { no } 12 \text { osób; } \\
\text { kampania } \\
\text { dotarła do } 1000 \\
\text { osób }\end{array}$ & $\begin{array}{l}\text {-Średnio-termi- } \\
\text { nowe wyniki } \\
\text { działań } \\
\text { - Np. w wyniku } \\
\text { szkoleń } 6 \text { osób } \\
\text { znalazło pracę }\end{array}$ & $\begin{array}{l}\text { - Szersza zmiana } \\
\text { społeczna } \\
\text { będąca } \\
\text { wynikiem } \\
\text { prowadzonych } \\
\text { działań } \\
\text { - Np. wzrost } \\
\text { inkluzji } \\
\text { społecznej }\end{array}$ \\
\hline
\end{tabular}

Źródło: opracowanie własne.

Przyszłość może nieść znaczną poprawę metod pomiaru. Przykładowo rewolucja technologiczna umożliwiła precyzyjniejsze formułowanie pytań badawczych i lepsze odpowiedzi, a także większą skrupulatność metod pomiaru (pozwolą nie tylko na ustalenie "jaki" wpływ udało się osiągnąć, ale także "jak" i „dlaczego" dana interwencja była lub nie była efektywna) [Gripper et al., 2017].

\subsection{Społeczny zwrot z inwestycji SROI}

Społeczny zwrot z inwestycji (SROI) jest narzędziem pomiaru wartości wytworzonej przez przedsiębiorstwo społeczne. Jest on przydatny w fazie szacowania wartości oraz jej monitoringu, a także komunikacji osiągnięć przedsiębiorstwa społecznego potencjalnym inwestorom. W odniesieniu do teorii zmiany jest to metodologia konfrontująca nakłady poniesione na interwencję o charakterze społecznym do rezultatów społecznych, korzyści społecznych wynikających z podjętych aktywności. Pomiar pomiar oddziaływania społecznego w szerokim ujęciu może być w tym przypadku zbyt trudny do przeprowadzenia.

Pomiar SROI prowadzony jest w zgodzie z siedmioma głównymi zasadami: zaangażowania interesariuszy, zrozumienia zmiany, 
wyceny tego, co najistotniejsze, włączania do pomiaru wartości czynników materialnych, nieprzeszacowywania, transparencji oraz weryfikacji wyników [Nicholls et al., 2012]. SROI opiera się na przypisywaniu wartości pieniężnych korzyściom natury społecznej lub ekonomicznej [Arvidson et al., 2010]. War- tość tę można wyrazić jako bieżącą wartość netto, zwrot z inwestycji czy relację korzyści do kosztów (ang. Cost to Benefit Analysis). Przykładowo SROI fundacji dotowanej z budżetu państwa o wartości 4 oznacza, że z 1 PLN dotacji wytwarza ona 4 PLN zysku społecznego.

$$
\mathrm{SROI}=\frac{\text { Bieżąca wartość netto korzyści społecznych }}{\text { Bieżąca wartość netto nakładów inwestycyjnych }}
$$

Oczywistym problemem wyliczania SROI jest w wielu przypadkach niemożność przypisania wartości pieniężnej niektórym korzyściom natury społecznej. Można wówczas szukać przybliżeń (ang. proxies), jak np. koszt noclegu dla organizacji dającej schronienie bezdomnym, jednak już koszt kampanii mającej na celu ochronę Puszczy Białowieskiej przed wycinką wymagałby ustalenia kosztu społecznego wycinki drzewa, co nie jest łatwe, choć powstały eksperymentalne metody ustalania go. Innym przykładem może być organizacja Panoptykon działająca na rzecz zwiększenia świadomości zagrożeń płynących z inwigilacji obywateli przez państwo lub korporacje, gdzie wyrażenie korzyści społecznych w kategoriach ekonomicznych byłoby niezwykle trudne.

\subsection{Metody zorientowane na beneficjenta}

Do kolejnych, niewykorzystanych w niniejszym studium przypadku, metod pomiaru wartości społecznej należą te zorientowane na użytkownika (beneficjenta): od metod o charakterze jakościowym, jak zbieranie historii, studia przypadku, dokumentacja foto lub video, grupy fokusowe, poprzez tradycyjne badania satysfakcji i zbieranie opinii zwrotnych, po metody eksperymentalne, jak obserwacje uczestników przez zewnętrznych specjalistów, powtarzalne testy standaryzowane oraz długotrwałe badania z wykorzystaniem grup kontrolnych (porównania grup dotkniętych interwencją z podobnymi grupami osób, które jej nie doświadczyły). Wraz z rewolucją technologiczną wzrasta wykorzystanie metod wizualizacji danych i badań satysfakcji beneficjentów (na skutek zwiększenia skali wykorzystania tabletów, laptopów i Internetu etc.).

Na potrzeby samej organizacji lub $w$ fazie poprzedzającej ewaluację istotne może być wykorzystanie metod o charakterze jakościowym. Mogą one być przydatne w formułowaniu wstępnych założeń i hipotez. Studia przypadku, badania antropologiczne, robienie zdjęć lub krótkich filmów, grupy fokusowe są dość łatwe do przeprowadzenia i jednocześnie bardziej niż inne metody skoncentrowane na beneficjencie, który jest głównym interesariuszem planowanej interwencji społecznej. Służyć więc mogą w fazie inspiracji.

Największą pewność mierzenia rzeczywistego wpływu społecznego interwencji o charakterze społecznym mamy w przypadku zastosowania metod eksperymentalnych, w których porównujemy grupę kontrolną, której nie dotyczy interwencja, z populacją dotkniętą interwencją. Pozwala to także z dużym prawdopodobieństwem ustalić, jaka część zmiany przypisana może być naszej interwencji, a jaka wystąpiłaby także bez niej, co powinno być później uwzględnione w analizach SROI. Do ich wad należy na pewno to, iż metody te są czasochłonne, kosztowne, a także wymagają znaczących kompetencji [SRI, 2014].

\section{Studium przypadku Fundacji Sławek}

Fundacja Sławek od 1998 r. pomaga osobom skazanym $\mathrm{w}$ readaptacji społecznej, którą organizacja definiuje jako „proces uzy- 
skiwania równowagi pomiędzy potrzebami więźnia a warunkami i wymogami otoczenia społecznego"11. Miarą sukcesu tego procesu jest przystosowanie byłego więźnia do życia zgodnego z literą prawa. Fundacja stara się świadczyć pomoc profesjonalnie, zatrudniając nie tylko ekspertów "z powołania”, ale także byłych skazanych, którzy dają przykład tego, że po opuszczeniu zakładu penitencjarnego można „wyjść na prostą".

Ze względu na niskie kwalifikacje zawodowe oraz wykształcenie, więźniowie opuszczający zakłady więzienne często borykają się z brakiem pracy oraz miejsca zamieszkania, co staje się często przyczyną ich wykluczenia społecznego. Marek Łagodziński - prezes Fundacji Sławek - twierdzi, iż problemem więźniów jest to, że ich wykluczamy, ale oni sami też się wykluczają. Po wyjściu na wolność myślą, że każdy - kto na nich spojrzy wie, że byli w więzieniu. Fundacja podejmuje więc pracę z nimi i ich rodzinami już w czasie pozbawienia wolności, tak aby przygotować ich do momentu wyjścia. W obiegowej opinii wyjście z więzienia jest utożsamiane ze szczęśliwą chwilą. W rzeczywistości dla więźniów to moment zetknięcia z wykluczeniem, które potęguje brak akceptacji rodziny, znajomych, czy pracodawców. Jedyne środowisko, które akceptuje ich bez zastrzeżeń to środowisko kryminalne.

Byli więźniowie zaraz po wyjściu na wolność odczuwają często przygnębienie i nie potrafią sobie poradzić w nowej rzeczywistości. Pracownicy Fundacji podkreślają, iż najważniejsze jest, aby trafiali oni pod ich opiekę zaraz po wyjściu z zakładu penitencjarnego, a nie po kilku miesiącach poszukiwania wsparcia. Fundacja świadczy kompleksową obsługę prawną, psychologiczną, doradczą, zawodową, socjalną. Każdemu z beneficjentów przygotowuje się tzw. indywidualny plan działania. Bezdomni, byli skazani mogą skorzystać z noclegu tymczasowego w ośrodku

https://www.fundacjaslawek.org/.
Fundacji w Mieni. Fundacja organizuje szereg projektów dotyczących pomocy więźniom oraz byłym skazanym. Przykładowo organizują opiekuna dla osób wychodzących na przepustki (Anioł Stróż), arteterapię, trening kontroli złości, projekty umacniające więzy rodzinne, pielgrzymki na Jasną Górę. Najnowszym projektem jest założenie przedsiębiorstwa społecznego Goji Land, które ma dawać zatrudnienie byłym osadzonym. Niniejszy artykuł koncentrować się będzie na pomiarze wartości społecznej wytworzonej przez fundację Sławek. Najpierw zbudowany zostanie model teorii zmiany, a następnie wyliczone zostanie SROI.

\subsection{Model logiczny i teoria zmiany}

Fundacja Sławek jako swój cel określa pomoc osobom przebywającym w zakładach penitencjarnych $\mathrm{w}$ bezpiecznym powrocie do społeczeństwa i do rodziny oraz działanie na rzecz pojednania i zbliżania ich rodzin dotkniętych izolacją. Teoria zmiany ukazuje, jak od początkowych nakładów poniesionych przez darczyńców prywatnych celem umożliwienia Fundacji realizacji jej celów, poprzez szereg projektów podejmowanych na rzecz skazanych i ich rodzin lub byłych skazanych, ich realizacji przez beneficjentów, aż po zmiany w środowisku byłych więźniów, takie jak ograniczenie recydywizmu, wzrost zatrudnienia, spadek zagrożenia uzależnieniami etc., Fundacja wypracowuje szerszy cel oddziaływania społecznego.

Teoria zmiany uwzględnia w tym przypadku 3 grupy beneficjentów: skazanych, ich rodziny oraz byłych skazanych i ukazuje, jak poszczególne projekty organizacji przyczyniają się do poprawy dobrostanu beneficjentów - do rezultatów podnoszących jakość ich życia (rys. 3).

W przypadku beneficjentów, którymi są więźniowie Fundacja przygotowała 4 główne projekty. Przede wszystkim organizowane są rozmowy indywidualne ze skazanymi, w trakcie których mogą oni opowiadać o swoich 

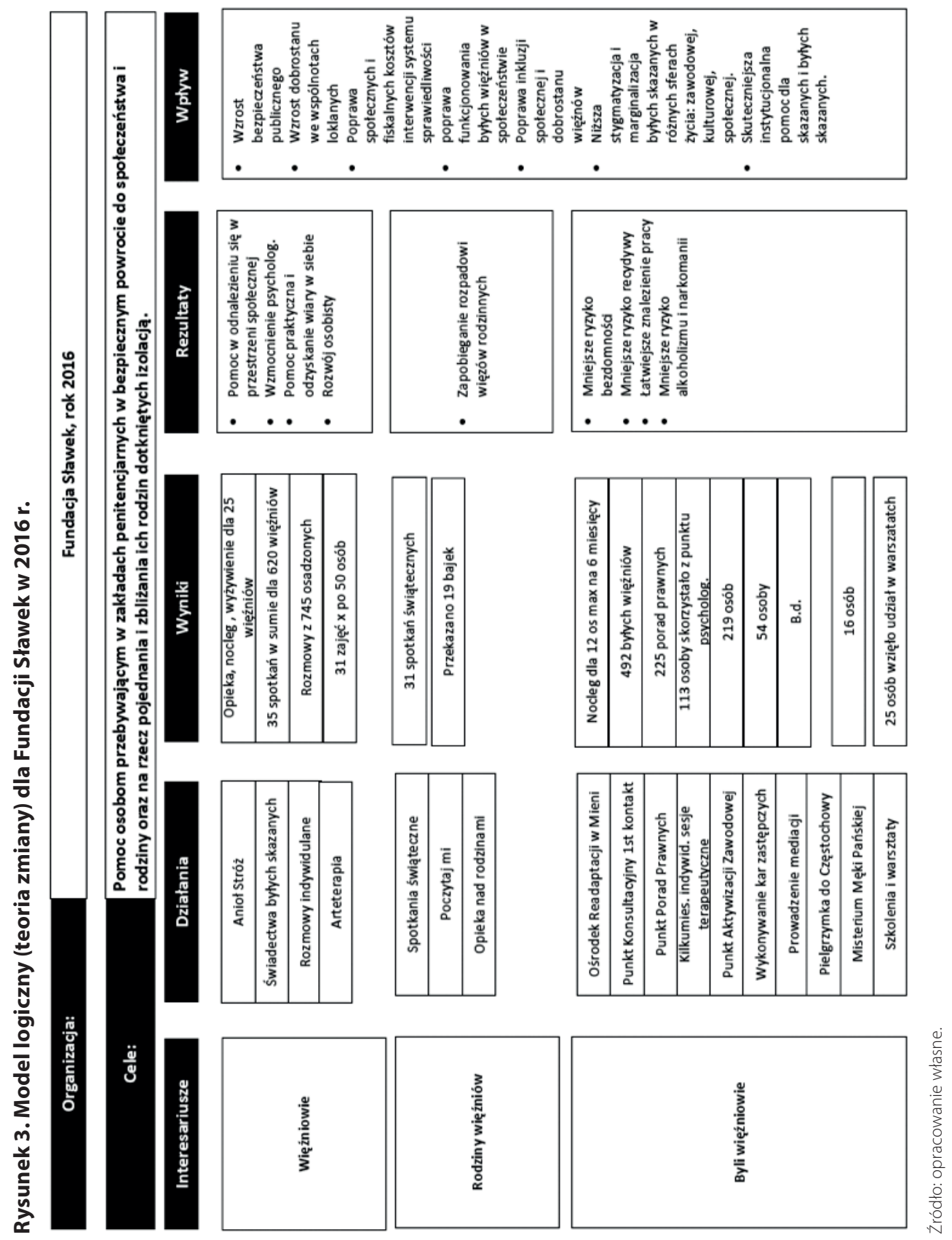
problemach zaufanej osobie, która udzieli im porady i zachowa dyskrecję. W 2016 r. przeprowadzono 745 takich rozmów. Ponadto, aby rozwiązać problem braku wiary więźniów w to, iż możliwe jest samodzielne życie wolne od przestępstw, prowadzony jest projekt „Świadectwa”, w którym byli skazani, którym po wyjściu udało się z sukcesem zacząć życie zawodowe, odbudować życie rodzinne i żyć w trzeźwości opowiadają, jakie podjęli w tym celu kroki po wyjściu na wolność. W roku 2016 r. w 35 spotkaniach udział wzięło 620 więźniów.

Dodatkowo prowadzony jest projekt "Anioł Stróż", gdzie wolontariusz udziela opieki więźniom na przepustce, czasem organizuje dla nich też nocleg. Pomaga to skazanym odnaleźć się w przestrzeni społecznej, pozbyć się uczucia zagubienia, także w miejscach takich jak pojazdy komunikacji miejskiej czy kawiarnia. Projekty te tworzą wartość w wymiarze pomocy psychologicznej a także praktycznych porad udzielanych przez członków Fundacji Sławek.

Kolejnym elementem działania Fundacji jest zapobieganie dezintegracji rodzin skazanych. Jej pracownicy zmierzają do budowy pojednania i odbudowy więzów rodzinnych. Dla najbliższych osób osadzonych realizowany jest program "Skazani na oczekiwanie". Korzysta z niego rocznie około 50 rodzin, drugie tyle korzysta z pomocy telefonicznie lub mailowo. Udzielane są im porady, wskazówki etc. W 2016 r. w mediacjach rodzinnych wzięło udział 5 osób. Fundacja organizuje także cotygodniowe spotkania z rodzinami, udziela licznych porad, organizuje wydarzenia czy uroczyste obiady rodzinne na terenie zakładu penitencjarnego. W 2017 r. rozbudowywany był, dzięki wsparciu Fundacji PZU, projekt „Poczytaj mi”, w którym skazani czytają dla swoich dzieci bajki, które po nagraniu na płytę CD z kilkoma słowami od rodzica przekazywane są dziecku.

Najintensywniej Fundacja pracuje jednak z byłymi skazanymi, chcąc zapewnić im moż- liwość rozpoczęcia nowego życia wolnego od przestępstw. Jednym z kluczowych celów jest zapobieganie mechanizmowi spychania ich na margines społeczny, gdzie akceptowani są tylko przez środowisko kryminalne, co kończy się recydywizmem. Dla byłych skazanych zagrożonych bezdomnością funkcjonuje ośrodek w Mieni, gdzie z noclegu korzystać może jednocześnie 12 osób, dla innych 120 osób rocznie organizowane są noclegi w innych miejscach. Fundacja ma też rozbudowaną infrastrukturę readaptacji społecznej i pomocy w aktywizacji zawodowej byłych więźniów: punkt konsultacyjny pierwszego kontaktu, punkt porad prawnych, punkt aktywizacji zawodowej, prowadzi mediacje, szkolenia i warsztaty. Dla niektórych osób prowadzone są także kilkumiesięczne indywidualne sesje terapeutyczne. Celem reintegracji społecznej organizowane są także: pielgrzymka do Częstochowy, gdzie byli skazani opiekują się osobami niepełnosprawnymi, misterium męki Pańskiej a także festiwale sztuki więziennej.

Szerszy i trudny do oszacowania wpływ działań Fundacji wiąże się ze wzrostem bezpieczeństwa publicznego, poprawą społecznych i fiskalnych kosztów interwencji systemu sprawiedliwości, czy wzrostem dobrostanu we wspólnotach lokalnych, a także poprawą funkcjonowania beneficjentów Fundacji w społeczeństwie - wzrostem inkluzji społecznej.

Do najważniejszych rezultatów działalności Fundacji Sławka należy redukcja kosztów społecznych, w tym zwłaszcza recydywizmu, a także obniżenie ryzyka rozpadu rodziny, spadek bezdomności wśród byłych skazanych, spadek uzależnień od alkoholu, spadek kosztów readaptacji społecznej i spadek bezrobocia. Ich kwantyfikacja oraz przypisanie wartości pieniężnych na podstawie znanych przybliżeń zostanie przeprowadzona w ramach analizy społecznego zwrotu z inwestycji SROI. 


\subsection{Wyliczenie SROI}

Społeczny zwrot z inwestycji jest wyliczany celem konfrontacji nakładów finansowych na interwencję społeczną z jej rezultatami społecznymi. Ma to pozwolić na oszacowanie jej efektywności. Punktem wyjścia są dane za 2016 r. Celem badania jest chęć podzielenia się z głównymi interesariuszami sukcesami organizacji w poprawie funkcjonowania byłych więźniów w społeczeństwie i zaprognozowanie rezultatów społecznych na najbliższe
5 lat. Wyliczenia obejmują nie tylko darowiznę oraz bezpośrednie zyski społeczne, ale także redukcję kosztów społecznych wynikających z działania Fundacji (tab. 2). Dla uproszczenia analizy oraz możliwości koncentracji na bezpośrednim wpływie pracy Fundacji odnotowane zostały tylko nakłady darczyńców, z pominięciem nakładów takich jak: praca wolontariuszy, posiadane budynki, ziemia, wsparcie ze strony instytucji publicznych (jak ośrodek pomocy społecznej, urząd pracy).

Tabela 2. Wyliczenia wartości społecznej wykreowanej przez Fundację Sławek

\begin{tabular}{|l|c|c|c|}
\hline & Per capita & Liczba 0sób & Razem \\
\hline Nakłady darczyńców & 584 & 650 & 379710 \\
\hline Redukcja kosztów społecznych & $\begin{array}{c}\text { Koszt } \\
\text { jednostkowy }\end{array}$ & Liczba 0sób & Razem \\
\hline redukcja recydywizmu & 39845 & 182 & 7269260 \\
\hline redukcja ryzyka rozpadu rodziny & 33461 & 50 & 1673030 \\
\hline spadek bezdomności & 9432 & 130 & 1226157 \\
\hline spadek alkoholizmu & 3439 & 4 & 13757 \\
\hline spadek kosztów readaptacji społecznej & 46388 & 1 & 46388 \\
\hline spadek bezrobocia & 10500 & 62 & 651000 \\
\hline Zyski społeczne & & & \\
\hline podatek odprowadzany (2000 PLN brutto) & 7845 & 62 & 486390 \\
\hline
\end{tabular}

Źródło: wyliczenia własne.

Pierwszą kwestią wymagającą poruszenia są nakłady darczyńców. W 2016 r. mimo narastającego zjawiska recydywizmu w Polsce, sięgającego 48\% skazanych wychodzących na wolność, podjęto decyzję o nie dotowaniu działalności Fundacji z budżetu Państwa. Stąd opiera się ona na dotacjach od prywatnych darczyńców. W 2016 r. wyniosły one 379710 zł. Nowopowstałe przy Fundacji Sławek przedsiębiorstwo społeczne Goji Land - plantacja bogatej w witaminy jagody goji otrzymało natomiast dotację od Fundacji La Caixa w wysokości 1254742 zł.

Drugą kategorią objętą wyliczeniami są bezpośrednie zyski społeczne w postaci zapłaconego podatku przez 62 podopiecz- nych Fundacji Sławek, którzy znaleźli zatrudnienie w 2016 r. W założeniach przyjęto ich wynagrodzenie w wysokości 2000 zł brutto, co przekłada się na wpływy do budżetu państwa w wysokości około 7845 zł rocznie na osobę.

Trzecią, najbardziej rozbudowaną kategorią jest redukcja kosztów społecznych będących rezultatem działania Fundacji Sławek, czyli kosztów, które nie zostaną poniesione przez społeczeństwo dzięki działaniu Fundacji. Można zaliczyć do nich ryzyko recydywizmu, rozpadu rodziny skazanego, bezdomności, alkoholizmu, kosztów readaptacji społecznej oraz bezrobocia, którymi dotkniętych jest wielu byłych skazanych. 
Koszty jednostkowe ukazane w tabeli 2 stanowią roczne szacunkowe koszty społeczne na osobę (recydywistę, alkoholika, bezdomnego etc.).

W obliczeniach SROI należy uwzględnić punkt odniesienia, czyli porównanie z grupą kontrolną byłych skazanych nie objętych interwencją. Mamy bowiem do czynienia z tzw. efektem jałowego biegu (ang. deadweight effect), który odwołuje się do korzyści, które uzyskano by tak czy inaczej, czyli bez ingerencji Fundacji Sławek [Oramus, 2011 s. 61]. Przykładowo recydywizm dotyka $48 \%$ wychodzących na wolność. Fundacja Sławek opiekuje się 650 osobami, co oznacza, że 312 z nich byłoby zagrożonych recydywą. W rzeczywistości do więzienia trafiło tylko 20\% podopiecznych Fundacji, czyli 130 osób². Oznacza to, iż działania Fundacji Sławek uratowały przez recydywą 182 osoby. Wynik ten przy kosztach więzienia i rozprawy sądowej szacowany jest na 39845 zł na skazanego recydywistę, co daje bardzo dużą oszczędność społeczną 7,3 miliona zł (bez uwzględniania kosztów systemu prewencji) ${ }^{3}$.

Pod ścisłą opieką Fundacji znalazło się 50 rodzin skazanych i byłych skazanych (szeroką opieką otoczono dużo więcej rodzin), do których skierowano rozbudowaną ofertę programową. Koszt społeczny rozbitej rodziny oszacowano na 33461 zł rocznie, co przy 50 uratowanych rodzinach daje oszczędność rzędu 1,7 mln zł. Przed bezdomnością natomiast uratowano 130 osób, co przy kosztach

\footnotetext{
Warto nadmienić, iż według wyjaśnień złożonych przez zarząd Fundacji Sławek, większość wyroków ich podopiecznych dotyczyła spraw z przeszłości i nie wchodzili oni w konflikt z prawem, będąc już podopiecznymi Fundacji. Mimo to autorka uwzględniła recydywizm podopiecznych w wysokości $20 \%$.

W pomiarze oddziaływania społecznego zwraca się także uwagę na efekty atrybucji (uwzględnienie wpływu innych organizacji czy instytucji na pożądany efekt) oraz przeniesienia (gdy zmiana społeczna ma inne niepożądane konsekwencje - o ich wartość należy pomniejszyć korzyść społeczną). W niniejszym artykule ustalono ich wartość na poziomie zerowym ze względu na trudność w ustaleniu występowania tych efektów.
}

bezdomności ustalonych na 9432 zł daje oszczędność społeczną w wysokości 1,2 mln zł. Pracę znalazły 62 osoby, co daje oszczędność społeczną w wysokości 651 tys. zł i podatek w wysokości 486 tys. zł. Terapią alkoholową Fundacja objęła 4 osoby. Koszty readaptacji społecznej (pomoc postpenitencjarna) zredukowano o 46 tys. zł.

Drugim projektem Fundacji Sławek jest przedsiębiorstwo Goji Land, którego biznesplan posłużył autorce do wyliczenia jego wartości społecznej i ekonomicznej (tab. 3). Przedsiębiorstwo przewiduje średnioroczny wzrost liczby etatów od około 7 w pierwszym roku działalności do około $23 \mathrm{w}$ roku piątym. Koszty jednostkowe są takie same jak w przypadku Fundacji Slawek, co daje wykreowaną wartość społeczną rosnącą od 232 tys. zł w roku pierwszym do 822 tys. zł w roku piątym.

Przy tak oszacowanej wartości społecznej wypracowanej przez oba zależne podmioty, można przejść do wyliczania bieżącej wartości netto NPV wykreowanej przez Fundację Sławek. Stopę dyskontową przyjęto w wysokości 3,5\%, a wysokość dotacji Fundacji Sławek oraz jej wykreowaną wartość społeczną na stałym poziomie, jak w 2016 r. Wartość ekonomiczną EV wytworzoną przez Fundację przyjęto na poziomie 0 , ze względu na jej wahania wokół tej wartości w ostatnich latach.

Dane zaprezentowane w tabeli 4 obrazują NPV korzyści społecznych i przepływów pieniężnych wygenerowanych przez Fundację Sławek i Goji Land. Wyższe wartości dla Fundacji niż dla Goji Landu wynikają przede wszystkim z większej liczby podopiecznych obsługiwanych przez Fundację. 
Tabela 3. Wyliczenia wartości społecznej wykreowanej przez Goji Land

\begin{tabular}{|l|r|r|r|r|r|}
\hline & \multicolumn{1}{|c|}{ Rok 1 } & \multicolumn{1}{|c|}{ Rok 2 } & \multicolumn{1}{c|}{ Rok 3 } & \multicolumn{1}{c|}{ Rok 4 } & \multicolumn{1}{c|}{ Rok 5 } \\
\hline Rocznie pracowników & 7 & 10 & 14 & 17 & 23 \\
\hline redukcja recydywizmu & 130859 & 207614 & 284370 & 335540 & 463465 \\
\hline spadek bezdomności & 30977 & 49146 & 67316 & 79429 & 109711 \\
\hline spadek alkoholizmu & 4518 & 7168 & 9818 & 11585 & 16002 \\
\hline Poradnictwo & 4552 & 7222 & 9892 & 11672 & 16122 \\
\hline Terapia & 9656 & 15319 & 20983 & 24758 & 34198 \\
\hline Podatek & 51530 & 81755 & 111979 & 132129 & 182504 \\
\hline RAZEM & 232092 & 368225 & 504358 & 595113 & 822002 \\
\hline
\end{tabular}

Żródło: obliczenia własne.

Tabela 4. Wyliczenia NPV dla Fundacji Sławek oraz Goji Land

\begin{tabular}{|l|c|c|c|c|c|c|}
\hline & Sławek nakłady & Sławek SV & Sławek netto & Goji Land EV & Goji Land SV & $\begin{array}{c}\text { Goji - wartość } \\
\text { mieszana }\end{array}$ \\
\hline Rok1 & 379710 & 11365982 & 10986271 & -561198 & 232092 & -329106 \\
\hline Rok 2 & 379710 & 11365982 & 10986271 & -180180 & 368225 & 188045 \\
\hline Rok3 & 379710 & 11365982 & 10986271 & 114570 & 504358 & 618928 \\
\hline Rok 4 & 379710 & 11365982 & 10986271 & 409320 & 595113 & 1004433 \\
\hline Rok5 & 379710 & 11365982 & 10986271 & 605820 & 822002 & 1427822 \\
\hline NPV & 1714412 & 51318004 & 49603591 & 259698 & 2233597 & 2493296 \\
\hline
\end{tabular}

* EV - wartość ekonomiczna

Źródło: obliczenia własne.

Wyniki SROI i wartości mieszanej (ang. blended value) zdominowane są przez bardzo wysoką wartość społeczną wykreowaną przez Fundację, która wynika przede wszystkim z niskich statystyk recydywizmu w grupie byłych skazanych będących pod jej opieką. Jej wartość bieżąca przy przyjętym okresie pięcioletnim wynosi ponad $51 \mathrm{mln}$ zł dla Fundacji (przyjęto zyski ekonomiczne na poziomie 0) oraz 2,5 $\mathrm{mln}$ dla przedsiębiorstwa społecznego. Szacuje się więc, iż w sumie oba podmioty wytworzą 53,8 mln zł wartości mieszanej w okresie pięcioletnim.

Kolejnym etapem jest wyliczenie społecznego zwrotu z inwestycji SROI dla obu podmiotów. Fundacja Sławek ma bardzo wysokie SROI równe 29,9, co oznacza, iż wytworzy 29,9 zł wartości społecznej na każdą zainwe- stowaną w jej działania złotówkę. Prognozy dla Goji Land są nieco mniej korzystne, ale SROI równe 1,8 wskazuje na szacowaną opłacalność społeczną planowanego przedsięwzięcia. Łączone SROI dla obu podmiotów przyjmuje wysoką wartość równą 18.

\section{Podsumowanie}

Niniejszy artykuł miał na celu prezentację najczęściej stosowanych metodologii pomiaru wartości społecznej wytwarzanej przez przedsiębiorstwa społeczne, czyli modelu logicznego oraz społecznego zwrotu z inwestycji SROI, z pominięciem porównania z grupą kontrolną ze względu na wysoki koszt badania i jego czasochłonność. Jeśli chodzi o szerszy i trudny do skwantyfikowania długoterminowy 
wpływ Fundacji, to działa ona na rzecz wzrostu bezpieczeństwa publicznego, poprawy społecznych i fiskalnych kosztów interwencji systemu sprawiedliwości. Nie bez znaczenia jest też długofalowy wpływ na dobrostan we wspólnotach lokalnych. Z punktu widzenia swoich beneficjentów Fundacja działa na rzecz poprawy ich funkcjonowania w społeczeństwie, przyczyniając się do wzrostu inkluzji społecznej.

\section{Literatura}

Arvidson M., Lyon F., McKay S., Moro D. (2010). The ambitions and challenges of SROI. Working Paper nr 49. Birmingham: TSRC, http://eprints.mdx.ac.uk/7104/1/ The_ambitions_and_challenges_of_SROI.pdf (dostęp: 20.03.2018).

Edens G., Lall S. (2014). The State of Measurement Practice in the SGB Sector. Aspen Network of Development Entrepreneurs, https://www.aspeninstitute. org/publications/state-measurement-practice-sgbsector (dostęp: 05.09.2017).

Gripper R., Kazimirski A., Kenley A., McLeod R., Weston A. (2017). Global innovations in measurement and evaluation. London: New Philanthropy Capital, https://www.thinknpc.org/wp-content/ uploads/2018/07/Global-Innovations-in-Measurement-Final-Interactive.pdf (dostęp: 20.03.2018).

Guthrie K., Louie J., David T., Foster C.C. (2005). The Challenge of Assessing Policy and Advocacy Activities: Strategies for a Prospective Evaluation Approach. Los Angeles: The California Endowment, http://www. theoryofchange.org/wp-content/uploads/toco_ library/pdf/2005_-_Guthrie_-_The_challenge_of_ assessing_policy_advocacy.pdf (dostęp: 20.03.2018). IMWG (2014). Measuring Impact: Subject paper of the Impact Measurement Working Group. The Impact Measurement Working Group of the Social Impact Investment Taskforce, https://www.thinknpc.org/ wp-content/uploads/2018/07/IMWG_MeasuringImpact1.pdf.

Kim M. (2015). Rethinking the Impact Spectrum. April 30, http://ashokau.org/blog/rethinking-the-impactspectrum/ (dostęp: 22.08.2017).

Nicholls J., Lawlor E., Neitzert E., Goodspeed T. (2012). A guide to social return on investment. Lothian: The SROI Network.

Olejniczak K. (2014). "Reguła 3E jako podstawa zarządzania współczesnym przedsiębiorstwem", Studia Ekonomiczne. Zeszyty Naukowe Uniwersytetu Ekonomicznego w Katowicach, nr 180, cz. 2, s. 208-216.
Po przypisaniu wartości pieniężnych rezultatom działań Fundacji, określonym w modelu logicznym, możliwe staje się wyliczenie społecznego zwrotu z inwestycji SROI oraz wartości mieszanej wytworzonej przez podmiot. Fundacja Sławek ze SROI równym 30 wytwarza 30 zł wartości społecznej z każdej zainwestowanej w jej działania złotówki. Dziwi więc decyzja zarządzających Funduszem Pomocy Postpenitencjarnej o zaprzestaniu dotowania jej działań od 2017 r.

Oramus M. (2011). „Przydatność metody Social Return on Investment dla małych podmiotów ekonomii społecznej. Studium przypadku fundacji Ale heca!", Ekonomia Społeczna, nr 2, s. 61-74.

Peersman G. (2014). „Overview: Data Collection and Analysis Methods in Impact Evaluation", Methodological Briefs: Impact Evaluation 10, Florence: UNICEF Office of Research.

Perek-Białas J., Worek B. (2007). „Ewaluacja interwencji społecznych", w: J. Hausner (red.), Zarzadzanie podmiotami ekonomii społecznej, skrypt 2 (s. 151-171). Kraków: Małopolska Szkoła Administracji Publicznej Uniwersytetu Ekonomicznego w Krakowie, http:// www.msap.uek.krakow.pl/doki/publ/es_zarzadzanie.pdf (dostęp: 22.08.2017).

SRI (2014). Social Reporting Standard. Guide to results-based reporting. Mülheim an der Ruhr: Social Reporting Initiative e.V, http://www.social-reporting-standard.de/fileadmin/redaktion/downloads/ SRS_guidelines_2014_EN.pdf.

Vogel V. (2012). Review of the use of 'Theory of Change' in international development. Review Report. UK Department of International Development, http:// www.theoryofchange.org/wp-content/uploads/ toco_library/pdf/DFID_ToC_Review_VogelV7.pdf (dostęp: 20.03.2018).

\section{Koszty roczne na osobę - źródła danych:}

1. Koszt więźnia - roczny (38 828 zł): www.sw.gov.pl

2. Pomoc postpenitencjarna (średni koszt świadczenia): www.sw.gov.pl

- Pokrywanie kosztów czasowego zakwaterowania lub schronienia w ośrodku dla bezdomnych (198 zł)

- Poradnictwo prawne, promocja zatrudnienia, aktywizacja zawodowa (33 zł)

- Programy podnoszące kompetencje społeczne, w tym zwłaszcza przeciwdziałanie agresji, przemocy, uzależnieniom (70 zł)

- Szkolenia i kursy podnoszące kwalifikacje zawodowe (957 zł) 
3. Koszt samotnego rodzicielstwa w Polsce (33 461 zł) - wyliczenia na podstawie: http://www.relationshipsfoundation.org

4. Koszt bezdomności (9 432 zł): https://www.researchgate.net/publication/308916373

5. Koszty alkoholizmu (3 439 zł): http://orka.sejm. gov.pl/WydBAS.nsf/0/16ca3bc940d9cf61c1257d5 0003663c8/ \$FILE/Koszty\%20ekonomiczno-spo\%C5\%82eczne.pdf

6. Koszt bezrobotnego (10 500 zł): http://www.bankier.pl/wiadomosc/10-5-mld-zl-to-roczny-kosztdlugotrwalego-bezrobocia-w-Polsce-2648958. html

\section{Measuring the social impact: An example of Slawek Foundation}

Summary: The article is aimed at presenting the most commonly used existing methods of measuring the social impact generated by a social enterprise using an example, a case study of Slawek Foundation. The Foundation serves the prisoners, ex-prisoners and their families with a goal of bringing them back to the society, so that they were able to return to life and live under the rule of law. The article is composed of a brief description of social value, social impact categories and the most commonly used methods of measuring the social value: the logic model (theory of change) and SROI, and next it shows a case study use of those methods for Slawek Foundation.

Keywords: social value, logic model, theory of change, SROI.

\section{Prawa autorskie i licencja / Copyright and License}

Artykuł opublikowano na licencji Creative Commons Uznanie autorstwa - Użycie niekomercyjne - Bez utworów zależnych 3.0 Polska http://creativecommons.org/licenses/by-nc-nd/3.0/pl/

This article is published under the terms of the Creative Commons Attribution - NonCommercial - NoDerivs (CC BY-NGND 3.0) License http://creativecommons.org/licenses/by-nc-nd/3.0/ 